University of Nebraska - Lincoln

DigitalCommons@University of Nebraska - Lincoln

\title{
Observational Analysis of the 27 May 1997 Central Texas Tornadic Event. Part II: Tornadoes
}

Adam L. Houston

Robert B. Wilhelmson

Follow this and additional works at: https://digitalcommons.unl.edu/geosciencefacpub

Part of the Earth Sciences Commons

This Article is brought to you for free and open access by the Earth and Atmospheric Sciences, Department of at DigitalCommons@University of Nebraska - Lincoln. It has been accepted for inclusion in Papers in the Earth and Atmospheric Sciences by an authorized administrator of DigitalCommons@University of Nebraska - Lincoln. 


\title{
Observational Analysis of the 27 May 1997 Central Texas Tornadic Event. Part II: Tornadoes
}

\author{
ADAM L. HOUSTON* \\ Department of Earth and Atmospheric Sciences, Purdue University, West Lafayette, Indiana \\ ROBERT B. WILHELMSON \\ National Center for Supercomputing Applications, and Department of Atmospheric Sciences, \\ University of Illinois at Urbana-Champaign, Urbana, Illinois
}

(Manuscript received 5 August 2005, in final form 24 May 2006)

\begin{abstract}
The 27 May 1997 central Texas tornadic event has been investigated in a two-part observational study. As demonstrated in Part I, the 1D environment associated with this event was unfavorable for significant $(\geq \mathrm{F} 2)$ tornadoes. Yet, the storm complex produced at least six significant tornadoes, including one rated F5 (the Jarrell, Texas, tornado). The purpose of this article is to examine the spatiotemporal interrelationships between tornadoes, preexisting boundaries, antecedent low-level mesocyclones, convective cells, and midlevel mesocyclones. It is shown that each of the six observed tornadoes that produced greater than F0 damage formed along the storm-generated gust front, not along preexisting boundaries. Half of these tornadoes formed on the distorted gust front, the portion of the storm-generated gust front whose orientation was deformed largely by the horizontal shear across the cold front. The remaining three tornadoes developed at the gust front cusp (the persistent gust front inflection located at the northeast end of the gust front distortion). Unlike the tornadoes south of the gust front cusp, these tornadoes are found to be associated with antecedent mesocyclones located in the low levels above the boundary layer. Furthermore, these mesocyclonic tornadoes are found to be larger and more destructive than the three nonmesocyclonic tornadoes. The formation of the Jarrell tornado is found to occur as a nearly stationary convective cell became collocated with a south-southwestward-moving low-level mesocyclone near the gust front cusp-a behavior that resembles the formation of nonsupercell tornadoes. It is argued that the back-building propagation/maintenance of the storm complex enabled this juxtaposition of convective cells with vorticity along the distorted gust front and may have therefore enabled tornado formation. Each of the convective cells without midlevel mesocyclones was found to remain farther from the boundaries than the mesocyclonic cells. Since the cells nearest to the boundaries were longer lived than the remaining cells, it is argued that cells near the boundaries were mesocyclonic because the boundaries yielded cells that were more likely to support temporally coherent midlevel rotation.
\end{abstract}

\section{Introduction}

The storm complex of the 27 May 1997 central Texas tornadic event developed in an environment that was unfavorable for significant $(\geq \mathrm{F} 2)$ tornadoes (Houston

* Current affiliation: Department of Geosciences, University of Nebraska at Lincoln, Lincoln, Nebraska.

Corresponding author address: Dr. Adam L. Houston, Department of Geosciences, University of Nebraska at Lincoln, 214 Bessey Hall, Lincoln, NE 68588.

E-mail: ahouston@unl.edu

DOI: 10.1175/MWR3301.1

(C) 2007 American Meteorological Society and Wilhelmson 2007, hereafter referred to as Part I), yet, it produced at least six significant tornadoes, including one rated F5 (the Jarrell, Texas, tornado; NCDC 1997). Ideally, analysis of this case should aim to reconcile the differences between the expected tornado potential and the observations. Unfortunately, the limited data available from this event preclude conclusive statements to this end. However, the data do allow for an examination of the spatiotemporal interrelationships between tornadoes, preexisting boundaries, antecedent low-level mesocyclones, convective cells, and midlevel mesocyclones and this serves as the objective of this article. Results from the analysis of interrelationships 
between tornadoes, boundaries, mesocyclones, and convective cells are reported in section 2 and a summary of results follows in section 3 .

\section{Analysis \\ a. Methodology}

As in Part I, radar data used for this work includes the Weather Surveillance Radar-1988 Doppler (WSR88D) level-II data from the New Braunfels, Texas (KEWX), and Fort Worth, Texas (KFWS) radars and the level-III data from the central Texas radar (KGRK). ${ }^{1}$ Updraft/cell identification and boundary positioning follows the methodology explained in Part I but since boundary positions are a key element of the following analysis, a summary of boundary characteristics is provided here.

Boundary positions were identified using combinations of temporally coherent features that were apparent in the available radar, satellite, and Automated Surface Observing System (ASOS) data: low-level radial velocity convergence as deduced from the $0.5^{\circ}$ elevation scans of the KGRK radar, radar reflectivity fine lines (Wilson and Schreiber 1986) appearing in the KGRK radar data, cloud lines or cloud field discontinuities appearing in 1-km visible satellite data, and the times and locations of airmass changes as sampled in the hourly ASOS data.

A summary of the surface boundary positions is illustrated in Fig. 1 (a full explanation of the boundary identification strategy and nomenclature can be found in Part I). The air mass southeast of all boundaries was "warm" and "moist" with southeasterly winds. The dryline separated the eastern air mass from an air mass with generally higher dry-bulb temperatures, lower dewpoint temperatures, and westerly winds. The dryline was primarily manifested as a cloud field discontinuity but also appeared as a reflectivity fineline. The cold front separated the air mass west of the dryline from an air mass with nearly identical surface dry-bulb temperatures but with generally northerly winds. The cold front appeared as a reflectivity fineline. The portion of the cold front that had overtaken the dryline and penetrated into the eastern air mass is referred to as the frontal segment. The storm-generated gust front appeared in the radar data as a reflectivity fine line and/or radial convergence signature. The por-

\footnotetext{
${ }^{1}$ Although the central Texas radar and the Gray Air Force Base surface observation station share the same three-letter station identifier (GRK), the radar is located at Granger Lake, not at the air force base.
}

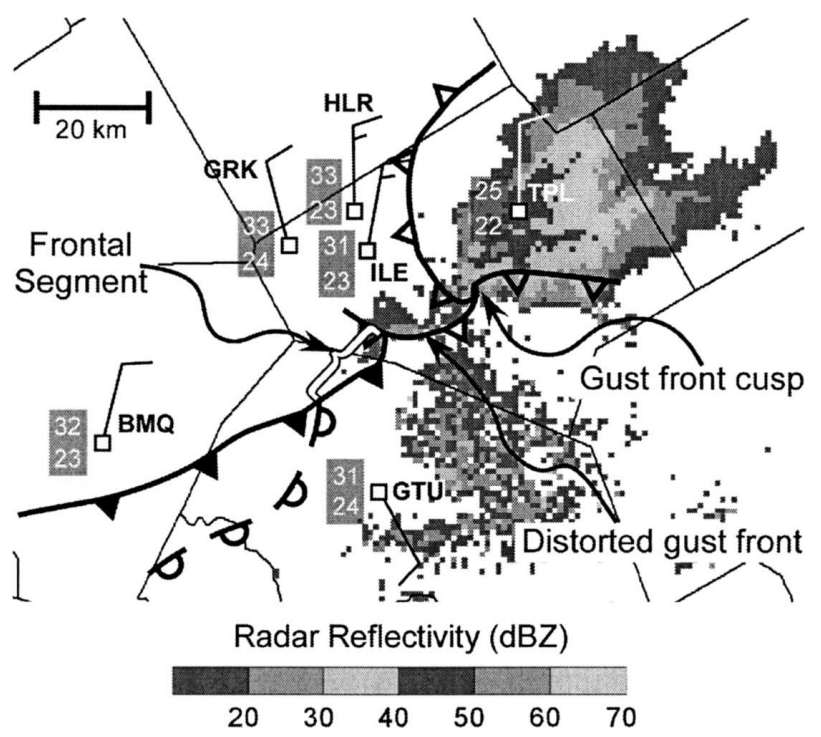

FIG. 1. Surface boundaries, surface observations, and low-level radar reflectivity field at 2000 UTC. The cold front appears as the curve with filled triangles, the dryline is the dashed and scalloped curve, and the storm-generated gust front is the curve with open triangles. The temperature and dewpoint $\left({ }^{\circ} \mathrm{C}\right)$ along with winds (half barbs represent $2.5 \mathrm{~m} \mathrm{~s}^{-1}$ and full barbs represent $5 \mathrm{~m} \mathrm{~s}^{-1}$ ) are included for selected stations. The reflectivity field is from the $0.5^{\circ}$ sweep of the KGRK radar.

tion of the gust front extending southwest from the precipitation field will be referred to as the distorted gust front $t^{2}$ and the gust front inflection at the northeast end of the distortion will be called the gust front cusp.

Tornado positions were determined through synthesis of Storm Data damage surveys (NCDC 1997) and velocity data from the $0.5^{\circ}$ elevation scans of the KGRK radar. Times of tornado formation and dissipation also utilized the observations of $\mathrm{L}$. Curtis (a central Texas TV meteorologist, 2002, personal communication). Table 1 provides a summary of the tornadoes of this event (well-sampled tornadoes appear in unshaded cells) and Fig. 2 illustrates the positions and tracks of the well-sampled tornadoes.

\section{b. Results}

\section{1) Tornadoes' Relationship to BOUNDARIES}

All but one of the well-sampled tornadoes (six of seven), and all of the well-sampled tornadoes with dam-

\footnotetext{
${ }^{2}$ As argued in Part I, the southwest extension of the gust front is considered "distorted" because, despite its resemblance to the rear-flank gust front associated with an archetypical supercell, the deformation of the observed gust front can be entirely explained by the differential advection of this boundary by the horizontal shear across the cold front. For further explanation, please refer to Part I.
} 
TABLE 1. Summary of tornadoes. Location, damage, path width, and italicized times are based on the damage surveys reported in Storm Data (NCDC 1997). Nonitalicized times are based on the observations of L. Curtis (2002, personal communication). The cells listed in the "nearest cell" column are those cells located closest to the tornado at the time of tornadogenesis. The names correspond to the cell names listed in Table 4. Boldface text represents tornadoes that were not included in the analysis.

\begin{tabular}{|c|c|c|c|c|c|c|}
\hline Tornado name & Location & Damage & $\begin{array}{c}\text { Path } \\
\text { width (yd) }\end{array}$ & $\begin{array}{l}\text { Lifetime } \\
\text { (UTC/min) }\end{array}$ & $\begin{array}{l}\text { Location relative } \\
\text { to boundaries }\end{array}$ & Nearest cell \\
\hline Lorena & $\begin{array}{l}6^{\circ} \mathrm{W} \text { of Lorena } \\
7^{\circ} \mathrm{W} \text { or Lorena }\end{array}$ & $\mathrm{F} 2$ & 75 & $1821-1833 / 12$ & $?$ & $?$ \\
\hline Eddy & Eddy & F0 & 40 & $1844-1847 / 3$ & $?$ & $?$ \\
\hline Moody & $\begin{array}{l}1^{\circ} \mathrm{E} \text { Moody } \\
7^{\circ} \mathrm{NW} \text { Troy }\end{array}$ & F3 & 150 & $1846-1910 / 24$ & Gust front cusp & 1851D \\
\hline Nolan Valley & $4^{\circ}$ WNW Belton & F0 & 40 & 1916-1927/11 & Frontal segment & 1908A \\
\hline Lake Belton & $\begin{array}{l}6.5^{\circ} \mathrm{N} \text { Belton } \\
5.6^{\circ} \mathrm{NW} \text { Belton }\end{array}$ & F3 & 275 & $1925-1945 / 23$ & Gust front cusp & $1924 A$ \\
\hline Stillhouse Dam & $5^{\circ} \mathrm{SW}$ Belton & F1 & 40 & 1950-1958/8 & Distorted gust front & 1908A \\
\hline Prairie Dell & $\begin{array}{l}1^{\circ} \mathrm{NW} \text { Prairie Dell } \\
2^{\circ} \mathrm{SW} \text { Prairie Dell }\end{array}$ & F1 & $100 *$ & $2007-2025 / 18$ & Distorted gust front & 1956A \\
\hline Jarrell & $\begin{array}{l}3^{\circ} \mathrm{N} \text { Jarrell } \\
5.5^{\circ} \mathrm{SW} \text { Jarrell }\end{array}$ & F5 & 650 & $2025-2053 / 28$ & Gust front cusp & $2002 A$ \\
\hline Georgetown & $4^{\circ} \mathrm{NW}$ Georgetown & $?$ & $?$ & $2050-2053 / 3$ & Distorted gust front & 2019A \\
\hline Cedar Park & $\begin{array}{l}3.5^{\circ} \mathrm{N} \text { Cedar Park } \\
2^{\circ} \mathrm{N} \text { Beecaves }\end{array}$ & F3 & 200 & $2105-2115 / 10$ & $?$ & $?$ \\
\hline Anderson Mill & $\begin{array}{l}0.5^{\circ} \mathrm{NW} \text { Four Points } \\
1^{\circ} \mathrm{W} \text { Four Points }\end{array}$ & F1 & 20 & $2115-2120 / 5$ & $?$ & $?$ \\
\hline Pedernales Valley & $\begin{array}{l}0.5^{\circ} \mathrm{W} \text { Lakeway } \\
3^{\circ} \mathrm{NW} \text { Beecaves }\end{array}$ & $\mathrm{F} 4$ & 440 & $2145-2210 / 25$ & $?$ & $?$ \\
\hline
\end{tabular}

* The path width of the Prairie Dell tornado is inconsistent with photographs and video of the tornado. The actual path was likely only tens of yards wide. The reported path width is more than likely associated with the early damage from the Jarrell tornado, which developed in the same location where the Prairie Dell tornado dissipated.

age exceeding an F0 rating, were found on the stormgenerated gust front and not on the preexisting boundaries (Table 1; well-sampled tornadoes appear in unshaded cells). This result is consistent with the findings of Magsig et al. (1998a,b). Three of the six tornadoes on the storm-generated gust front were found at the gust front cusp (the Moody, Lake Belton, and Jarrell, Texas, tornadoes) while the remaining three developed south of the cusp and north of the gust front's intersection with the frontal segment.

Airmass boundaries can be sources of surface/nearsurface vorticity (with vertical and/or horizontal components) as well as upward motion. While the available data are insufficient for quantifying the horizontal vorticity or vertical motion in place along the boundaries, surface observations across the boundaries can be used to estimate the vertical vorticity. To do this, surface observations at 2000 UTC were used to approximate a wind vector behind each boundary along with an approximate wind vector in the air mass to the east of the dryline. These winds were then projected onto a unit vector tangential to each boundary (assuming identical boundary orientations) to compute the boundarytangential wind velocity differential, which serves as a proxy for vertical vorticity, assuming a uniform distri- bution of the observed winds along each boundary. Results appear in Table 2. A similar approach was used in Part I to approximate the convergence along the three boundaries. Because of uncertainties in the representa-

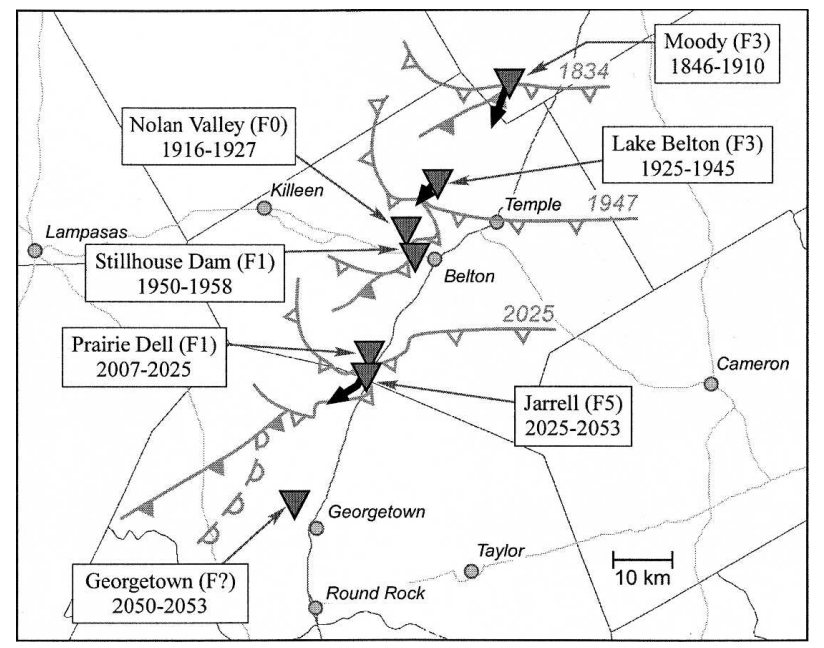

FIG. 2. Names, positions, tracks, times, and damage rating for the seven tornadoes examined in this article. Inverted triangles represent the initial locations of tornadoes and black arrows represent the path lengths and directions of motion. Boundaries at 1824, 1947, and 2025 UTC are illustrated in gray as in Fig. 1. 
TABLE 2. Boundary-tangential wind velocity differentials across the dryline, frontal segment, and distorted gust front at 2000 UTC. The computation assumes a $4 \mathrm{~m} \mathrm{~s}^{-1}$ wind from $170^{\circ}$ east of the dryline and a boundary orientation of $30^{\circ}$ north of east (south of west). The velocity differential is computed by subtracting the boundary-tangential wind vector east of the boundaries from the boundary-tangential wind vector behind each boundary.

\begin{tabular}{lcc}
\hline \hline \multicolumn{1}{c}{ Boundary } & $\begin{array}{c}\text { Wind vector } \\
\text { behind boundary }\end{array}$ & $\begin{array}{c}\text { Boundary-tangential } \\
\text { velocity differential } \\
\left(\mathrm{m} \mathrm{s}^{-1}\right)\end{array}$ \\
\hline Dryline & $5 \mathrm{~m} \mathrm{~s}^{-1}$ from $280^{\circ}$ & -2.2 \\
Frontal segment & $7 \mathrm{~m} \mathrm{~s}^{-1}$ from $350^{\circ}$ & 3.9 \\
$\begin{array}{c}\text { Distorted storm } \\
\text { gust front }\end{array}$ & $7 \mathrm{~m} \mathrm{~s}^{-1}$ from $20^{\circ}$ & 8.2 \\
\hline
\end{tabular}

tiveness of the winds across the boundaries, a technique was employed in Part I that quantified the statistical significance of the differences in velocity differentials between each of the boundaries. This technique is applied to the velocity differentials computed here and the results are listed in Table 3. The velocity differentials listed in Table 2 clearly indicate that the estimated vertical vorticity is positive along both the frontal segment and distorted gust front. It is also clear that the values are largest along the distorted gust front. Because the errors imparted to the boundary-tangential winds must be very large to compromise the statistical significance of the velocity differential differences, this conclusion is considered robust.

\section{2) Tornadoes' Relationship to LOW-LEVEL MESOCYCLONES}

Unlike the tornadoes south of the gust front cusp, all three of the gust-front cusp tornadoes were associated with antecedent rotation in the low levels above the boundary layer. This elevated rotation resided in the 1.5-3-km AGL layer approximately $11-18 \mathrm{~min}$ prior to tornadogenesis. As illustrated in Fig. 3, the vortices that produced the observed radial shear signatures were less than $4 \mathrm{~km}$ in diameter (based on the maximum azimuthal velocity differences). Because the scale of these vortices was found to be independent of their distance from the radar, they appeared to have been accurately resolved by the KGRK radar. Fujita (1981) defined vortices with diameters between 0.04 and $4 \mathrm{~km}$ as misocyclones but this is an arbitrary threshold and, as demonstrated by Burgess et al. (1993), mesocyclone diameters can be less than $4 \mathrm{~km}$. Thus, for simplicity, the antecedent vortices will be referred to as mesocyclones.

Each of the mesocyclonic tornadoes (Moody, Lake Belton, and Jarrell) produced F3 or greater damage while the three nonmesocyclonic tornadoes along the
TABLE 3. The maximum relative errors in the boundarytangential winds that are possible for the velocity differential values to be statistically significant at the $95 \%$ confidence interval.

\begin{tabular}{lc}
\hline \hline \multicolumn{1}{c}{ Boundaries } & $\begin{array}{c}\text { Max error allowed } \\
\text { for statistically } \\
\text { significant } \\
\text { differences }\end{array}$ \\
\hline Dryline-frontal segment & $1005 \%$ \\
Dryline-distorted storm gust front & $1006 \%$ \\
Distorted storm gust front-frontal segment & $380 \%$ \\
\hline
\end{tabular}

distorted gust front (Stillhouse Dam, Prairie Dell, and Georgetown, Texas) produced no worse than F1 damage. To the extent that the surveyed damage accurately reflects maximum winds speeds, it could be concluded that the strongest tornadoes were associated with antecedent mesocyclones. The observed mesocyclonic tornadoes were also found to be considerably larger than nonmesocyclonic tornadoes. Note from Table 1 that the three mesocyclonic tornadoes had path widths exceeding $150 \mathrm{yd}$ while the path widths of all other tornadoes were $<75 \mathrm{yd}^{3}{ }^{3}$ The relationship between path widths, wind speeds, and observed damage is uncertain for this case; nevertheless, it is clear that the mesocyclonic tornadoes differed considerably from their nonmesocyclonic counterparts.

\section{3) Tornadoes' Relationship to Convective CELLS}

The cell identification and tracking performed for this case revealed numerous convective cell mergers (Table 4). Previous observational (e.g., Lemon 1976; Westcott 1984) and modeling (e.g., Finley et al. 2001) studies have demonstrated that cell mergers can enhance both the vertical velocity and vertical vorticity of the consolidated updraft. Therefore, the relationship between tornadoes and cell mergers is examined to identify potential (qualitative) temporal correlations. Figure 4 illustrates the timeline of well-sampled tornadoes and merger times. Mergers are matched to tornadoes if the consolidated updraft is, or becomes, spatially juxtaposed with the tornado. Three of the cell mergers occurred after tornadogenesis (1908, 1924, and 2037 UTC), two of the tornadoes experienced no mergers prior to tornadogenesis or while the tornado was reported (Lake Belton and Georgetown), and two of the tornadoes experienced mergers approximately

\footnotetext{
${ }^{3}$ The video of the Prairie Dell tornado reveals that the path width reported in Storm Data (NCDC 1997) should be much smaller.
} 
a) 1834 UTC $-0.5^{\circ}(\sim 900 \mathrm{~m} \mathrm{AGL})$
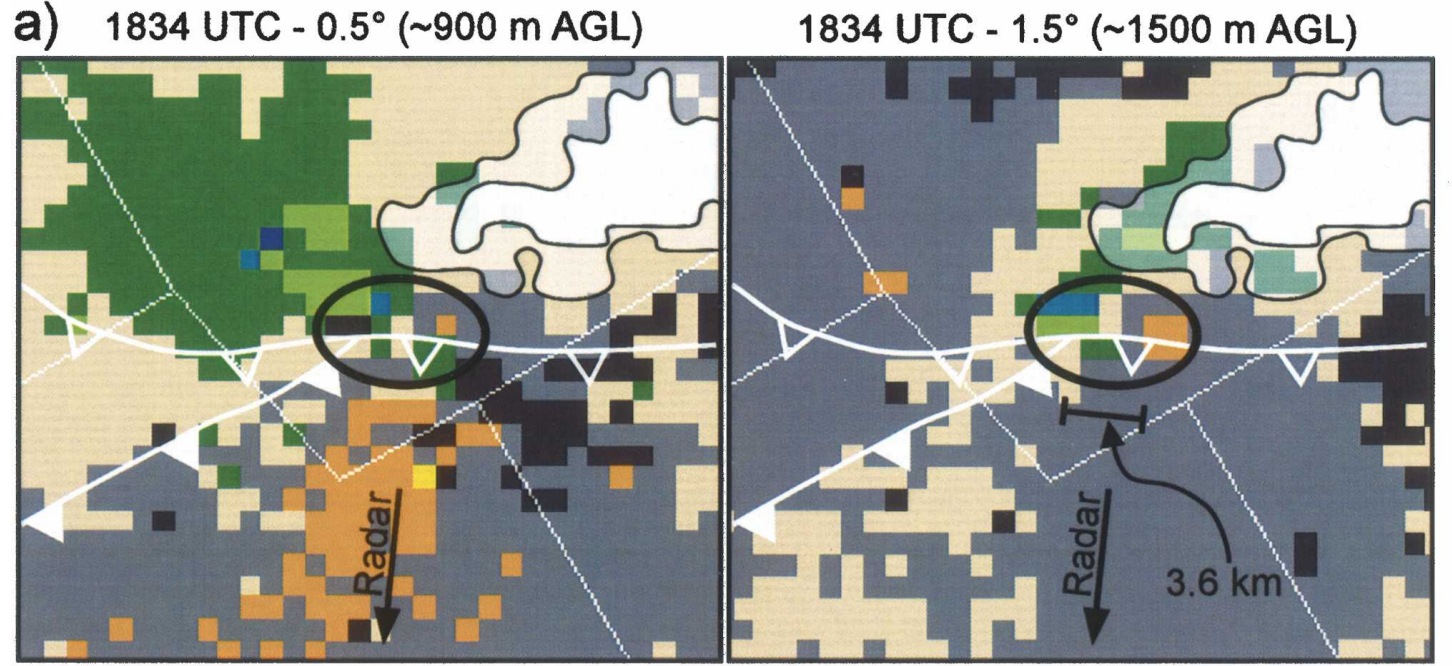

b) $1921 \mathrm{UTC}-0.5^{\circ}(\sim 600 \mathrm{~m} \mathrm{AGL})$
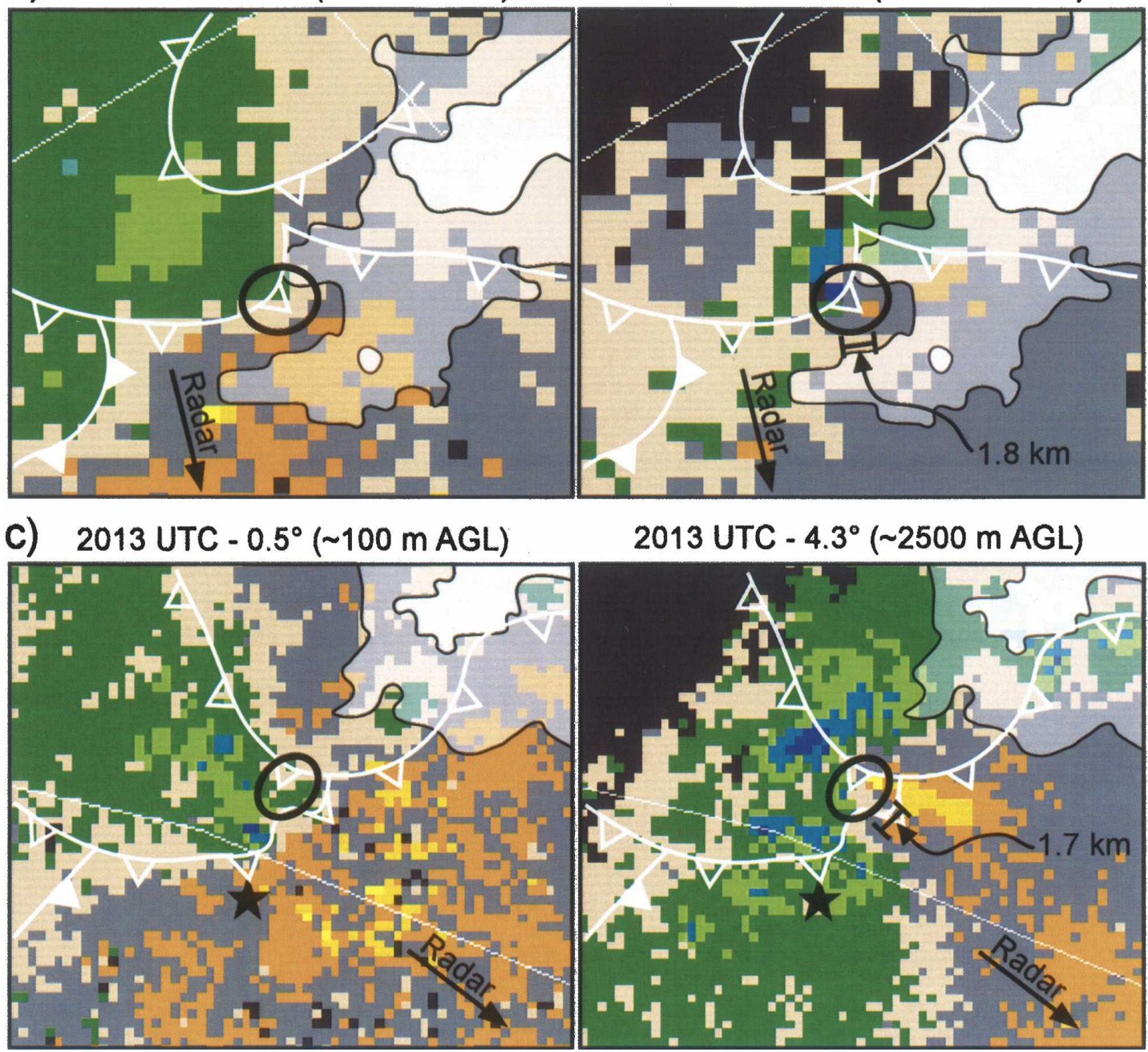

FIG. 3. Antecedent mesocyclones associated with tornadoes at the gust front cusp at (a) 1834, (b) 1921, and (c) 2013 UTC, corresponding to times shortly before the development of the Moody, Lake Belton, and Jarrell tornadoes, respectively. (left) The KGRK $0.5^{\circ}$ elevation radial velocity field (shaded following the key on the right), surface boundaries (same as in Fig. 1), reflectivity values $\geq 30 \mathrm{dBZ}$ (gray semitransparent region) and $\geq 50 \mathrm{dBZ}$ (white semitransparent region) from the $0.5^{\circ}$ elevation scan of the KGRK radar, and the location of the elevated mesocyclone (black ellipse). (right) The radial velocity field from the sweep of the KGRK radar corresponding to the approximate elevation of the mesocyclone. 
TABLE 4. Merger statistics for all cells identified between 1851 and 2048 UTC. Cell nomenclature follows that used in Table 5 of Part I (the numeric part of the cell name corresponds to either the time of cell initiation or, for the 1851 UTC cells, the start of the analysis). Mergers are listed with the longer-lived of the two cells contributing to the merger; an " $\mathrm{M}$ " indicates that a merger occurred with this cell and has been associated with another cell.

\begin{tabular}{cl}
\hline \hline Cell name & Mergers (in UTC) \\
\hline $1851 \mathrm{~A}$ & None \\
$1851 \mathrm{~B}$ & None \\
$1851 \mathrm{C}$ & M \\
$1851 \mathrm{D}$ & At 1908 with 1851C \\
$1908 \mathrm{~A}$ & At 1924 with 1914A \\
& At 1941 with 1930A \\
& At 1944 with 1941A \\
$1914 \mathrm{~A}$ & M \\
$1924 \mathrm{~A}$ & None \\
$1930 \mathrm{~A}$ & M \\
$1936 \mathrm{~A}$ & None \\
$1941 \mathrm{~A}$ & M \\
$1956 \mathrm{~A}$ & At 2002 with 1956B \\
$1956 \mathrm{~B}$ & M \\
$2002 \mathrm{~A}$ & At 2037 with 2025A \\
$2007 \mathrm{~A}$ & None \\
$2013 \mathrm{~A}$ & None \\
2019A & At 2043 with 2037A \\
$2025 \mathrm{~A}$ & M \\
2031A & None \\
$2031 \mathrm{~B}$ & None \\
2037A & M \\
\hline
\end{tabular}

5-10 min prior to tornadogenesis (Stillhouse Dam and Prairie Dell). It is interesting to note that of the seven cell mergers that were observed, only one of the consolidated updrafts (corresponding to the merger at 2043 UTC) was not associated with an observed tornado. However, the fact that mergers preceded only two of the tornadoes indicates that, for this case, cell mergers were not good predictors of tornadogenesis. Nevertheless, it should be noted that the 2037 UTC merger occurred near the time that the Jarrell tornado "expanded quickly into a very large vortex nearly $1 / 2$ mile in width" (NCDC 1997). While this evidence is merely circum- stantial, it may indicate that, despite the variability in the temporal relationships between cell mergers and tornadoes, mergers occurring during ongoing tornadoes might have resulted in tornado intensification.

The interaction between tornadoes, convective cells, and low-level mesocyclones is another noteworthy characteristic of this event. An example of this interaction is represented by the relationship between cell 2002A and the Jarrell tornado. As illustrated in Fig. 5, formation of the Jarrell tornado corresponded to the spatiotemporal collocation of the (at the time) stationary cell $2002 \mathrm{~A}$ and the south-southwestward-moving low-level mesocyclone. This process of tornadogenesis following collocation of an updraft with an antecedent parent circulation resembles the conceptual model of nonsupercell tornadogenesis proposed by Wakimoto and Wilson (1989) and illustrated in Fig. 6. In their model, tornado formation follows the intercept of a misocyclone with an existing updraft. Drawing analogy to the Wakimoto and Wilson model for nonsupercell tornadogenesis is not intended to imply that tornadogenesis in this event can be attributed to similar processes, that is, the stretching of preexisting boundary layer vertical vorticity (Roberts and Wilson 1995; Lee and Wilhelmson 1997). Even though preexisting vertical vorticity was in place (Table 2), the inability to quantify the contribution to tornadogenesis from all sources of vorticity means that such attribution would be highly speculative.

It can be argued, however, that this relationship between convective cells, low-level mesocyclones, and tornadoes was only possible in this event because of the back-building propagation/maintenance of the storm complex. New cells developing along the distorted gust front and to its southwest along the frontal segment became juxtaposed with the localized maximum of (vertical and/or horizontal) vorticity along the southsouthwestward-moving distorted gust front. These new cells were in position to amplify this vorticity into tornadic-strength vortices.

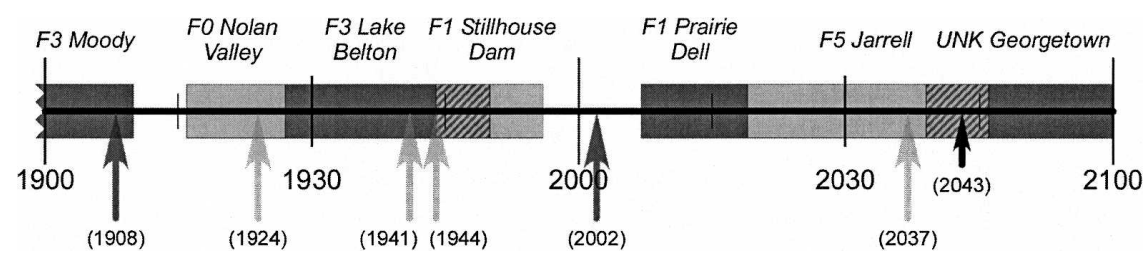

FIG. 4. Relationship between cell mergers and tornadogenesis. Shaded bars represent the duration of individual tornadoes (the corresponding tornado name appears above each bar) and the matching arrows (matched by the shade of gray) represent the times of mergers (the approximate time is listed below each arrow). A tornado is matched to a specific merger if the consolidated updraft is, or becomes, spatially juxtaposed with the tornado. The black arrow represents a merger unmatched to a tornado. 

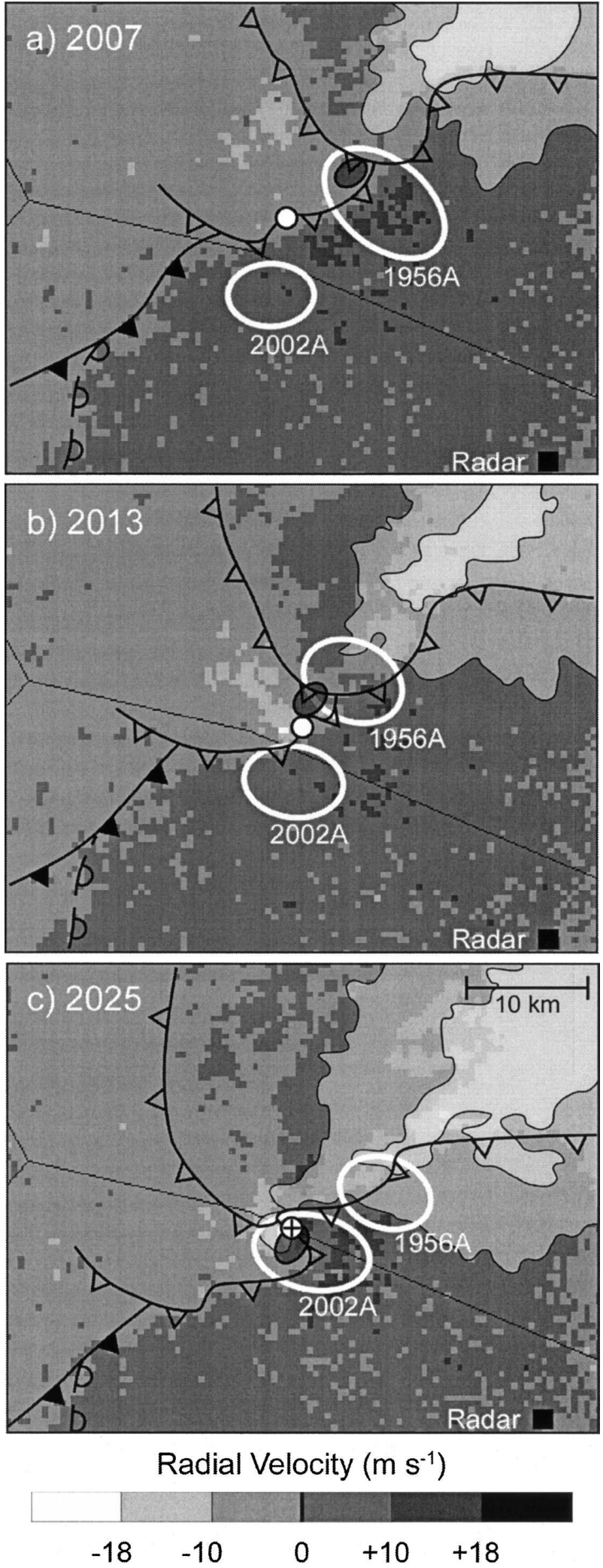

FIG. 5. Formation of the Jarrell tornado. Observed and diagnosed fields at (a) 2007, (b) 2013, and (c) 2025 UTC. The radial velocity field from the $0.5^{\circ}$ elevation sweep of the KGRK radar is

\section{4) MidleVel MeSOCyClONES' RELATIONSHIP TO} BOUNDARIES

Each of the three cells without midlevel mesocyclones (2007A, 2013A, and 2019A; Part I) remained, on average, farther from preexisting and storm-generated boundaries than the mesocyclonic cells (Table 5). ${ }^{4}$ This relationship between midlevel mesocyclones and boundaries suggests that the close proximity to these boundaries might have been essential for mesocyclone generation. Three possible explanations for this relationship seem to be the most tractable: 1) low-level vertical vorticity present along these boundaries directly contributed to the mesocyclones, 2) updrafts were stronger along these boundaries and therefore more likely to support mesocyclonic-strength midlevel rotation, and 3) updrafts were longer lived along these boundaries and therefore more likely to support temporally coherent midlevel rotation [temporal coherence is one of the criteria typically used for mesocyclone detection (Stumpf et al. 1998) and was specifically used in Part I for this case].

As illustrated in Table 2, positive vertical vorticity was in place along the distorted gust front and frontal segment but not along the dryline. Since the midlevel mesocyclones of this event were cyclonic, a contribution from preexisting vertical vorticity would require that cells remained near either the frontal segment or distorted gust front. The adjusted cell-boundary distances are reflected in the fourth column of Table 5 and indicate that the mesocyclonic cells were indeed much closer to these two boundaries than the nonmesocyclonic cells. However, the direct contribution to mesocyclones from this vertical vorticity cannot be confirmed with the available data.

Intuitively, it is reasonable to expect stronger updrafts along boundaries owing to the associated augmentation of vertical motion from the enhanced ascent.

\footnotetext{
${ }^{4}$ The average distance between a cell and boundary is computed using the first $3 / 4$ of the cell's lifetime. This is done to approximately neglect the position of the cells while they are dissipating.

$\leftarrow$

shaded following the key at the bottom, the reflectivity values $\geq 30$ (50) $\mathrm{dBZ}$ from the $0.5^{\circ}$ elevation scan of the KGRK radar are shaded in semitransparent gray (white), surface boundaries are illustrated as in Fig. 1, the locations of cells 2002A and 1956A are denoted with white ellipses, and the locations of the antecedent mesocyclone are denoted with semitransparent black ellipses. The plain white circles in (a), (b) illustrate the locations of the Prairie Dell tornado and the white circle with a plus symbol in (c) denotes the position of the Jarrell tornado.
} 


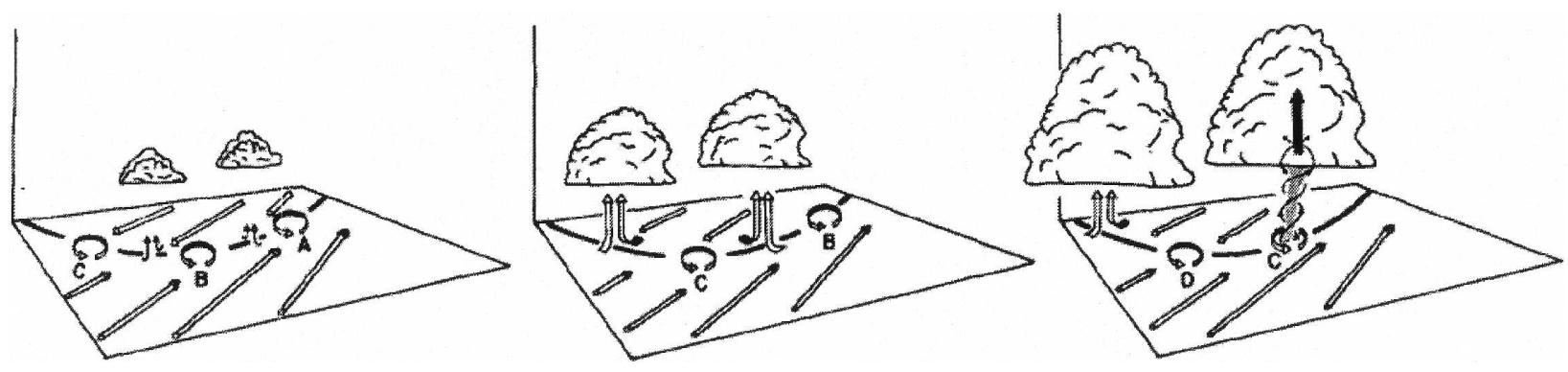

FIG. 6. Conceptual model of nonsupercell tornadogenesis from Wakimoto and Wilson (1989).

However, it is impossible to quantify updraft strength with the data available for this case. Thus, it is impossible to correlate updraft strength and cell-boundary separation.

The average lifetime of the five cells nearest to the boundaries (cells 1851D, 1908A, 1924A, 1936A, and 2002A) was approximately $45 \mathrm{~min}$ while the average lifetime of the remaining three long-lived cells (2007A, 2013A, and 2019A) was approximately $30 \mathrm{~min}$ (Table 5). Calculating the Student's $t$ statistic on these samples reveals that the means are statistically significant at the $98 \%$ confidence interval. However, because the samples are so small they may not represent the true populations, and thus the validity of this statistic is questionable. In as far as these samples are representative it can be concluded that the updrafts were indeed longer lived along these boundaries. As demonstrated in Part I, cell maintenance appeared to rely on the boundaries, thus, it could be argued that the boundaries were responsible for longer-lived cells and were therefore more likely to support temporally coherent midlevel rotation.

\section{Summary}

The work presented in this article was designed to complete the observational component of this exami- nation of the 27 May 1997 central Texas tornadic event. In the first part of the observational component (Part I), the prestorm environment of the event was examined along with the role played by preexisting and storm-generated boundaries on storm maintenance and propagation. In this portion of the observational component, an analysis of the observed tornadoes was reported. This analysis focused on the spatiotemporal interrelationships between tornadoes, preexisting boundaries, antecedent low-level mesocyclones, convective cells, and midlevel mesocyclones. The notable observations and conclusions from this analysis are as follows:

- Each of the six observed tornadoes that produced greater than F0 damage was found along the stormgenerated gust front, not along preexisting boundaries.

- Only the three tornadoes at the gust front cusp (the persistent gust front inflection located at the northeast end of the gust front distortion) were associated with antecedent low-level mesocyclones.

- Each of the three mesocyclonic tornadoes (at the gust front cusp) produced F3 or greater damage and had path widths greater than $150 \mathrm{yd}$, while the three nonmesocyclonic tornadoes produced no worse than F1 damage and had path widths less than $75 \mathrm{yd}$.

- Although numerous convective cell mergers were ob-

TABLE 5. Statistics for the longest-lived, well-sampled cells. The presence or absence of midlevel mesocyclones along with cell durations are based on the analysis presented in Part I. The ranking of the average distance between a cell and either the frontal segment or distorted gust front is included to simplify the interpretation.

\begin{tabular}{|c|c|c|c|c|c|}
\hline \multirow[b]{2}{*}{ Cell name } & \multirow{2}{*}{$\begin{array}{l}\text { Midlevel } \\
\text { mesocyclone }\end{array}$} & \multirow{2}{*}{$\begin{array}{l}\text { Avg distance between } \\
\text { cell and any boundary } \\
(\mathrm{km})\end{array}$} & \multicolumn{2}{|c|}{$\begin{array}{l}\text { Avg distance between cell and } \\
\text { frontal segment or distorted gust front }\end{array}$} & \multirow{2}{*}{$\begin{array}{l}\text { Duration } \\
(\min )\end{array}$} \\
\hline & & & (rank) & $(\mathrm{km})$ & \\
\hline $2007 \mathrm{~A}$ & No & 10.9 & 6 & 11.6 & 30 \\
\hline $2013 \mathrm{~A}$ & No & 8.0 & 7 & 11.9 & 30 \\
\hline 2019A & No & 4.5 & 8 & 13.4 & $\geq 29$ \\
\hline $1908 \mathrm{~A}$ & Yes & 2.3 & 3 & 2.3 & 54 \\
\hline 1851D & Yes & 2.1 & 5 & 6.0 & $\geq 45$ \\
\hline $1936 \mathrm{~A}$ & Yes & 1.7 & 2 & 1.9 & 55 \\
\hline $2002 \mathrm{~A}$ & Yes & 1.6 & 1 & 1.6 & $\geq 46$ \\
\hline $1924 \mathrm{~A}$ & Yes & 1.0 & 4 & 3.0 & 29 \\
\hline
\end{tabular}


served during this event, their inconsistent temporal relationship with tornadogenesis indicated that cell mergers were not good predictors of tornadogenesis in this case.

- The temporal relationship between the observed intensification of the Jarrell tornado and a cell merger suggests that mergers occurring during ongoing tornadoes might have resulted in tornado intensification.

- The distorted gust front (where six of the seven tornadoes were observed) was characterized by positive vertical vorticity that was larger than the vertical vorticity in place along the other boundaries.

- The development of the Jarrell tornado occurred as a nearly stationary convective cell became collocated with a south-southwestward-moving low-level mesocyclone near the gust front cusp. This behavior resembles the Wakimoto and Wilson model for nonsupercell tornadogenesis. It is argued that the backbuilding propagation/maintenance of the storm complex enabled this juxtaposition of convective cells with (vertical and/or horizontal) vorticity along the distorted gust front and may have therefore enabled tornado formation.

- Each of the three cells without midlevel mesocyclones remained farther from preexisting and stormgenerated boundaries than the mesocyclonic cells. While a precise explanation for this observation is not possible given the available data, cells nearest to the boundaries were found to be on average 50\% longer lived than the remaining cells. Thus, it is possible that cells near the boundaries were mesocyclonic because the boundaries yielded cells that were more likely to support temporally coherent midlevel rotation.

While the observational analysis presented above and in Part I provides many insights into the role of preexisting boundaries in the 27 May 1997 central Texas event, a number of questions remain unanswered (and virtually unanswerable through observational analysis alone). In the second component of this work, results will be presented from numerical experiments conducted to further explore the role that preexisting and storm-generated boundaries can play in backbuilding propagation/maintenance and storm rotation in high-CAPE, low-shear environments.

Acknowledgments. We would like to sincerely thank M. Gilmore, L. Curtis, and J. Trapp for reviewing ear- lier versions of this paper. We are grateful for the careful critiques of several anonymous reviewers that greatly improved the quality of this paper. We would also like to thank E. Rasmussen, M. Ramamurthy, B. Rauber, L. Wicker, B. Jewett, and B. Lee for their insightful discussions regarding this work. Thanks also go to M. Magsig for providing the level-III KGRK data. L. Curtis' well-documented tornado observations along with R. Igau's chase video greatly assisted the analysis. Funding for this work was provided through NSF Grants ATM-9986672 and ATM-0449753.

\section{REFERENCES}

Burgess, D. W., R. J. Donaldson Jr., and P. R. Desrochers, 1993: Tornado detection and warning by radar. The Tornado: Its Structure, Dynamics, Prediction, and Hazards, C. R. Church, Ed., Vol. 79, Amer. Geophys. Union, 203-221.

Finley, C. A., W. R. Cotton, and R. A. Pielke Sr., 2001: Numerical simulation of tornadogenesis in a high-precipitation supercell. Part I: Storm evolution and transition into a bow echo. $J$. Atmos. Sci., 58, 1597-1629.

Fujita, T. T., 1981: Tornadoes and downbursts in the context of generalized planetary scales. J. Atmos. Sci., 38, 1511-1534.

Houston, A. L., and R. B. Wilhelmson, 2007: Observational analysis of the 27 May 1997 central Texas tornadic event. Part I: Prestorm environment and storm maintenance/propagation. Mon. Wea. Rev., 135, 701-726.

Lee, B. D., and R. B. Wilhelmson, 1997: The numerical simulation of nonsupercell tornadogenesis. Part I: Initiation and evolution of pretornadic misocyclone circulations along a dry outflow boundary. J. Atmos. Sci., 54, 32-60.

Lemon, L. R., 1976: The flanking line, a severe thunderstorm intensification source. J. Atmos. Sci., 33, 686-694.

Magsig, M. A., D. W. Burgess, and R. R. Lee, 1998a: Multiple boundary evolution and tornadogenesis associated with the Jarrell, Texas events. Preprints, 19th Conf. on Severe Local Storms, Minneapolis, MN, Amer. Meteor. Soc., 186-189.

— J. J. LaDue, D. W. Burgess, and R. R. Lee, 1998b: A radar and satellite analysis of tornadic storm updraft evolution on 27 May 1997. Preprints, 16th Conf. on Weather Analysis and Forecasting, Phoenix, AZ, Amer. Meteor. Soc., 320-322.

NCDC, 1997: Storm Data. Vol. 39, No. 5, 229 pp.

Roberts, R. D., and J. W. Wilson, 1995: The genesis of three nonsupercell tornadoes observed with dual-Doppler radar. Mon. Wea. Rev., 123, 3408-3436.

Stumpf, G. J., A. Witt, E. D. Mitchell, P. L. Spencer, J. T. Johnson, M. D. Eilts, K. W. Thomas, and D. W. Burgess, 1998: The National Severe Storms Laboratory mesocyclone detection algorithm for the WSR-88D. Wea. Forecasting, 13, 304-326.

Wakimoto, R. M., and J. W. Wilson, 1989: Non-supercell tornadoes. Mon. Wea. Rev., 117, 1113-1140.

Westcott, N., 1984: A historical perspective on cloud mergers. Bull. Amer. Meteor. Soc., 65, 219-226.

Wilson, J. W., and W. E. Schreiber, 1986: Initiation of convective storms at radar-observed boundary layer convergence lines. Mon. Wea. Rev., 114, 2516-2536. 